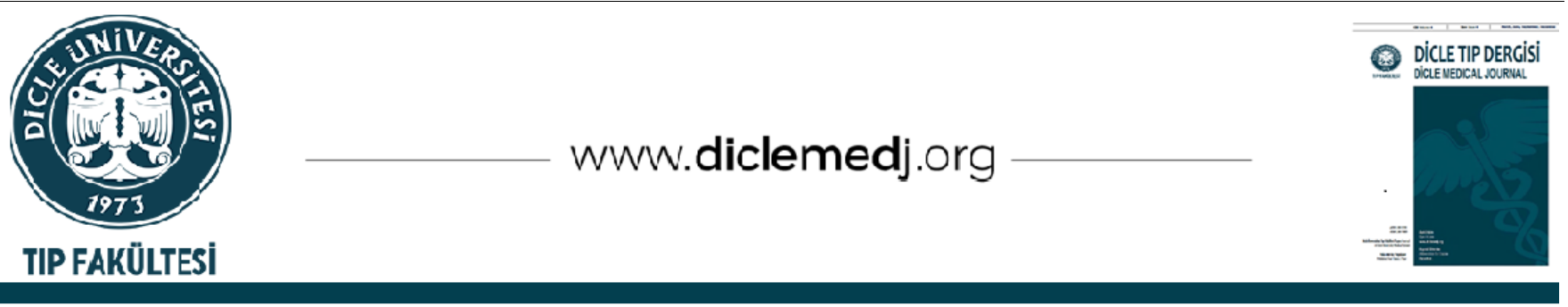

Original Article / Özgün Araştırma

\title{
Evaluation of factors affecting morbidity, mortality, and graft survival in kidney transplant patients
}

\author{
Muhammed Emre Sevim ${ }^{1}$, Fatma Yilmaz Aydin ${ }^{1}{ }_{1}$, Emre Aydin ${ }_{2}$ \\ 1 Department of Internal Medicine, School of Medicine, University of Dicle, Diyarbakır, Turkey \\ 2 Department of Nephrology, School of Medicine, University of Dicle, Diyarbakır, Turkey
}

Received: 14.09.2021; Revised: 20.09.2021; Accepted: 22.09.2021

\begin{abstract}
Objective: The aim of this study is to examine and evaluate the clinical findings and affecting factors related to graft and patient survival in kidney transplant patients at Dicle University Hospital.

Method: 72 patients who underwent kidney transplantation at Dicle University Medical Faculty Hospital between January 2012 and September 2019 were included in the study. Demographic characteristics of patients, transplantation types, clinical and laboratory findings, pre-transplant dialysis types, renal failure etiologies, post-transplant complications, average patient and graft survival times and patient characteristics at the time of diagnosis, laboratory values, and treatment modalities were investigated.
\end{abstract}

Results: In this study, the data collected from 72 patients who had kidney transplantation and 68 donors was analysed. The mean age of the patients was $32,7 \pm 13,8$ years. 31 of patients were female, 41 were male. 56 of the transplants were performed living donors and 12 from cadavers. 9 patients died. The mean of patient survival was $94 \pm 3,4$ months. Graft loss occured in 15 patients. The mean of graft survival was $86 \pm 4,3$ months. Acute rejection occured in 10 patients. Chronic allograft nephropathy occured in 19 patients. Chronic allograft nephropathy was found more frequently in patients with acute rejection $(p=0.017)$. In addition, graft loss was more common in patients with chronic allograft nephropathy $(\mathrm{p}=0.002)$. The dialysis duration was less than 12 months, and the BMI of the recipient was below 30 had a positive effect on patient survival.

Conclusion: Recipient obesity and long-term dialysis programs reduce patient survival. In addition, prevention of rejection has a positive effect on patient and graft survival.

Keywords: Kidney Transplantation, Acute Rejection, Graft Survival

DOI: 10.5798/dicletip.1000251

Correspondence / Yazıșma Adresi: Fatma Yilmaz Aydin, Department of Internal Medicine, School of Medicine, University of Dicle,Diyarbakır, Turkey email:fatmay83@hotmail.com 


\section{Böbrek nakli yapılan hastalarda morbidite, mortalite ve greft sağkalımına etki eden faktörlerin değerlendirilmesi}

Öz

Amaç: Bu çalışmanın amacı Dicle Üniversitesi Hastanesi'nde böbrek nakli yapılan hastalarda greft ve hasta sağkalımına ilişkin klinik bulguları ve etki eden faktörleri incelemek ve değerlendirmektir.

Yöntemler: Çalışmaya Ocak 2012- Eylül 2019 tarihleri arasında Dicle Üniversitesi Tıp Fakültesi Hastanesi'nde böbrek nakli yapılan 72 hasta dahil edildi. Çalışmaya dahil edilen hastaların demografik özellikleri, nakil tipleri, klinik ve laboratuvar bulguları, nakil öncesi diyaliz tipleri, böbrek yetmezliği etyolojileri, nakil sonrası gelișen komplikasyonlar, ortalama hasta ve greft sağkalım süreleri ve bu süreleri etkileyen tanı anındaki hasta özellikleri, laboratuvar değerleri, tedavi modaliteleri araştırıldı.

Bulgular: Çalışmamızda böbrek nakli yapılan 72 hastanın ve 68 vericinin verileri analiz edildi. Hastaların ortalama yaşı $32,7 \pm 13,8$ yıldı. 31 kadın, 41 erkek hasta vardı. Nakillerin 56'sı canlıdan, 12'si kadavradan yapılmıştı. Ortalama hasta

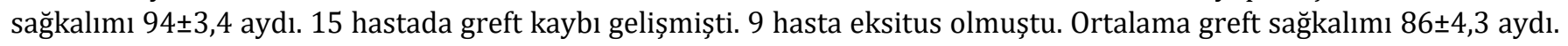
10 hastada akut rejeksiyon gelişmiști. 19 hastada kronik allograft nefropatisi gelişmişti. Kronik allograft nefropatisi, akut rejeksiyon gelişen hastalarda $(p=0,017)$ daha sık saptandı. Ayrıca kronik allograft nefropatisi gelişen hastalarda greft kaybı daha sık olmaktaydı $(\mathrm{p}=0,002)$. Alıcının diyaliz süresinin $\leq 12$ ay ve $B K I \leq 30$ olması hasta sağkalımını olumlu etkilemişti.

Sonuç: Alıcı obezitesi ve uzun süreli diyaliz programları hasta sağkalımını azaltmaktadır. Ayrıca rejeksiyonun önlenmesinin, hasta ve greft sağkalımına olumlu etkisi olmaktadır.

Anahtar kelimeler: Böbrek nakli, Akut Rejeksiyon, Greft Sağkalımı.

\section{INTRODUCTION}

Chronic kidney injury (CKD) can be defined as abnormalities in kidney structure and function lasting more than 3 months. For this, glomerular filtration rate (GFR) should be $<60 \mathrm{ml} / \mathrm{min} / 1.73$ $\mathrm{m} 2$ or kidney damage markers should be shown. These markers are; albuminuria, urinary sediment abnormalities, tubular abnormalities, histological abnormalities, imaging abnormalities, and a history of kidney transplant ${ }^{1}$. The prevalence of CKD in Turkey has been reported as $15.7 \%{ }^{2}$.

When GFR is $<15 \mathrm{ml} / \mathrm{min}$, the stage of end-stage renal disease (ESRD) is mentioned ${ }^{3}$. Renal replacement therapy is started in patients with ESRD. These are hemodialysis, peritoneal dialysis, and kidney transplantation. Kidney transplantation is the best treatment option for end-stage renal disease ${ }^{4}$. Selection of donor and recipient is of great importance in kidney transplantation. Although it improves the patient's quality of life and saves the patient from dialysis complications, close follow-up is required in terms of surgical complications, graft losses, immunosuppressive therapy, and recurrence.

Graft rejections due to human leukocyte antigen (HLA) incompatibility between donor and recipient are extremely important for graft survival $^{5}$. Graft rejections are classified as hyperacute, acute and chronic. Hyperacute rejection is a condition that develops within minutes after transplantation due to HLA and AB0 antigens. Today, it is rarely seen with the increased sensitivity of crossmatch tests ${ }^{6}$. Although acute rejection develops within days or weeks, this situation can be occurred months later. Since the clinic is mostly asymptomatic, it should be considered in case of an increase in serum creatinine. To call it acute rejection, delayed graft function and pre-post renal causes must be excluded. Chronic rejection develops over months or years. It is related to the antibody or $\mathrm{T}$ lymphocyte-related immune response. It is the most important cause of graft loss in the first year after transplantation 7 . However, recently, the success of kidney transplantation has increased significantly, especially in parallel with a clearer 
understanding of the immunology of allograft rejection and new developments in the prevention and treatment of rejection.

There are many reasons that affect graft and patient survival in kidney transplantation other than HLA compliance. Although there is no clear consensus on the effect of these causes, it guides us about the results of the transplant.

The aim of our study is to examine and evaluate the clinical findings and affecting factors related to graft and patient survival in kidney transplant patients at Dicle University Hospital.

\section{METHOD}

In this study, 72 patients who had kidney transplantation in Dicle University Medical Faculty Hospital between January 1, 2012, and September 1, 2019, were evaluated retrospectively. Patients who were transferred in our center and followed up in another center and were not transferred in our center were not included in the study.

Demographic data (age, gender, body mass index, blood group), primary kidney diseases, nontransplant renal replacement treatments and durations, donor types (living, cadaver), transplantation durations, rejection times, causes and durations of graft loss and mortality of all patients included in the study were scanned from the hospital automation system and patient files. Renal function tests (urea, creatinine, albumin, GFR), spot urine protein/creatinine ratios, 24-hour urine protein levels were screened in the pre- and post-transplant follow-ups of the patients. This study was approved by Dicle University Faculty of Medicine local ethics committee (22.10.2020/48).

Statistical analyzes of the results obtained in the study were performed using SPSS (Statistical Package for the Social Sciences) 26 statistical software packages. Descriptive statistics were expressed as mean \pm standard deviation, minimum and maximum values for continuous variables, while categorical variables were expressed as numbers and percentages. In addition, the Chisquare test was used in the analysis of categorical variables (such as age, gender, body mass index, dialysis type, dialysis duration, rejection types). Overall survival, within-group survival, and survival

of 6 months, 1 , and 2 years were measured using the Kaplan-Meier test. A p value less than 0.05 in these tests was considered statistically significant.

\section{RESULTS}

72 kidney transplant patients were included in the study. There were 56 live donors and 12 cadavers. The mean age of the donors was $39.9 \pm 15.9$ years. 39 (57.4\%) were female and 29 (42.6\%) were male. The mean body mass index (BMI) was 26.8 \pm 4.2 . Transplantation was performed from the right kidney in $23(31.9 \%)$ patients and from the left kidney in 49 (68.0\%). Transplantation was performed from both right and left kidneys of 4 cadavers. Demographic data of all patients are given in Table I.

Table I: Demographic and Clinical Data of All Patient Groups

\begin{tabular}{|c|c|}
\hline Parameters & n:72 (\%) \\
\hline \multicolumn{2}{|l|}{ Mean age (year) } \\
\hline Recipient & $32.7 \pm 13.8$ \\
\hline Donor & $39.9 \pm 15.9$ \\
\hline \multicolumn{2}{|l|}{ Gender } \\
\hline Recipient women & $31(43.1)$ \\
\hline Recipient men & $41(56.9)$ \\
\hline Donor women & $39(57.4)$ \\
\hline Donor men & $29(42.6)$ \\
\hline \multicolumn{2}{|l|}{ Mean BMI } \\
\hline Recipient & $25.5 \pm 5.3$ \\
\hline Donor & $26.8 \pm 4.2$ \\
\hline \multicolumn{2}{|l|}{ Dialysis types ${ }^{1}$} \\
\hline Hemodialysis & $48(66.7)$ \\
\hline Peritoneal dialysis & $8(11.1)$ \\
\hline Preemptive & $14(19.4)$ \\
\hline \multicolumn{2}{|c|}{ Mean dialysis duration (month) } \\
\hline Hemodialysis & $33.0 \pm 46.6$ \\
\hline Peritoneal dialysis & $32.2 \pm 26.4$ \\
\hline \multicolumn{2}{|l|}{ Donor $^{2}$} \\
\hline Living & $56(77.8)$ \\
\hline Cadaver & $12(22.2)$ \\
\hline
\end{tabular}


When the blood group was analyzed, 30 patients $(41.7 \%)$ who underwent kidney transplantation had blood group A, 24 patients (33.3\%) blood group 0, 12 patients (16.7\%) blood group B, and 6 patients (8.3\%) was the AB. In addition, when hepatitis serology was examined, hepatitis B serology was positive in 4 patients (5.6\%).

When the patients transplanted from living donors and cadavers were examined, a significant portion of those transplanted from a living donor were men. Moreover, the mean duration of dialysis patients with transplants from cadaver was longer (Table II). In living donors, 31 patients (55.4\%) with 1st degree relatives, 13 patients with 2 nd degree $(23.2 \%)$ and 9 patients $(16.1 \%)$ who were transplanted from their spouses were identified. 3 patients $(5.4 \%)$ were distant relatives. The effect of transplants from living donors and cadavers on rejection and survival is shown in Table III.

Table II: Comparison of the Whole Patient Group to Living Donors and Cadavers

\begin{tabular}{|c|c|c|c|}
\hline Parameters & $\begin{array}{l}\text { Living: } 56 \\
\text { (\%) }\end{array}$ & $\begin{array}{l}\text { Cadaver:12 } \\
\text { (\%) }\end{array}$ & $\mathbf{p}$ \\
\hline Mean age (year) & $33.7 \pm 13.8$ & $29.3 \pm 13.8$ & 0.259 \\
\hline Age & & & 0.012 \\
\hline$\leq 18$ & $5(8.9)$ & $6(37.5)$ & \\
\hline$>18$ & $51(91.1)$ & $10(62.5)$ & \\
\hline Gender & & & 0.019 \\
\hline Women & $20(35.7)$ & $11(68.8)$ & \\
\hline Men & $36(64.3)$ & $5(31.3)$ & \\
\hline Mean BMI & $27.0 \pm 4.5$ & $20.5 \pm 4.8$ & $<0.001$ \\
\hline \multicolumn{4}{|l|}{ Dialysis types } \\
\hline Hemodialysis & $40(71.4)$ & $8(50)$ & 0.109 \\
\hline Peritoneal dialysis & $3(5.3)$ & $5(31.3)$ & 0.011 \\
\hline Preemptive & $13(23.2)$ & $1(6.3)$ & 0.169 \\
\hline Mean dialysis duration (month) & $16.1 \pm 17.9$ & $83.2 \pm 56.1$ & $<0.001$ \\
\hline
\end{tabular}

Table III: The Effect of Living Donor and Cadaver on Rejection, Graft Loss and Mortality in the Whole Patient Group

\begin{tabular}{|llll|}
\hline Parameters & $\begin{array}{l}\text { Living: } \\
\mathbf{5 6}(\%)\end{array}$ & $\begin{array}{l}\text { Cadaver: } \\
\mathbf{1 2}(\%)\end{array}$ & $\mathbf{p}$ \\
\hline Mean patient survival (month) & $\mathbf{9 4 . 1 \pm 3 . 8}$ & $87.9 \pm 7.2$ & 0.997 \\
Mean graft survival (month) & $\mathbf{8 9 \pm 4 . 5}$ & $71.1 \pm 10.3$ & 0.226 \\
Acute rejection & $\mathbf{7 ( 1 2 . 5 )}$ & $3(18.8)$ & 0.682 \\
Chronic allograft nephropathy & $\mathbf{1 7 ( 3 0 . 4 )}$ & $2(12.5)$ & 0.207 \\
Graft loss & $\mathbf{1 0 ( 1 7 . 9 )}$ & $5(31.3)$ & 0.299 \\
Mortality & $\mathbf{7 ( 1 2 . 5 )}$ & $2(12.5)$ & 1 \\
\hline
\end{tabular}

Acute rejection developed in 10 patients (13.9\%) and chronic allograft nephropathy in 19 patients (26.4\%). Chronic allograft nephropathy developed in $6(60 \%)$ of those who had acute rejection and 13 $(21 \%)$ of those who did not $(p=0.017)$.

Graft loss developed in 15 patients (20.8\%). The most common cause was chronic allograft nephropathy with 7 patients (46.7\%). Two patients $(13.3 \%)$ had vascular congestion, and one patient had recurrent glomerulonephritis, newly developed glomerulonephritis, renal artery thrombosis and polyoma virus nephropathy. Etiology was not found in two patients. Graft survival rates are shown in Figure 1. Graft loss developed in $9(47.4 \%)$ patients who developed chronic allograft nephropathy and 6 (11.3\%) patients who did not ( $\mathrm{p}=0.002)$.

9 patients $(12.5 \%)$ died. The most common cause of death was pneumonia (44.4\%). Cerebrovascular event developed in two patients (22.2\%) and hypertensive pulmonary edema in one patient (11.1\%). The etiology was unknown in two patients. Patient survival rates are shown in Figure 1

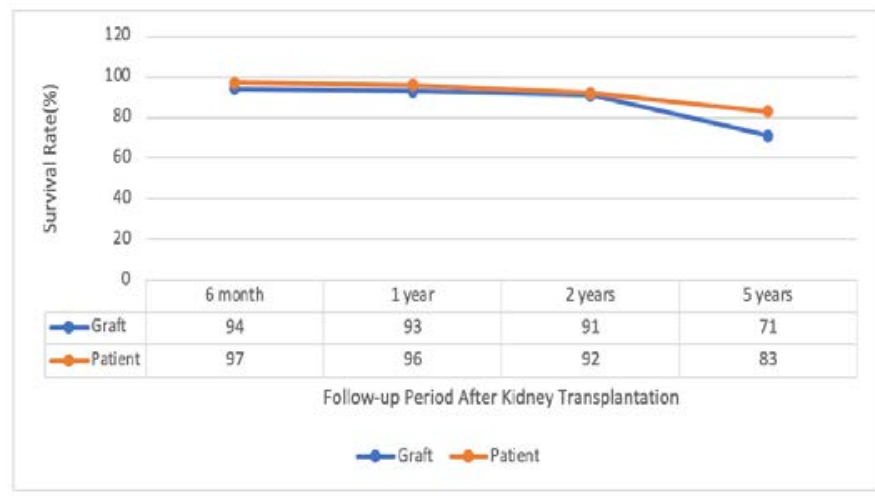

Figure 1. Patient and Graft Survival in the Entire Patient Group 
When the etiology of chronic renal failure was evaluated, the most common cause was hypertension. It was followed by chronic glomerulonephritis. The etiologies of chronic renal failure are given in Figure 2.

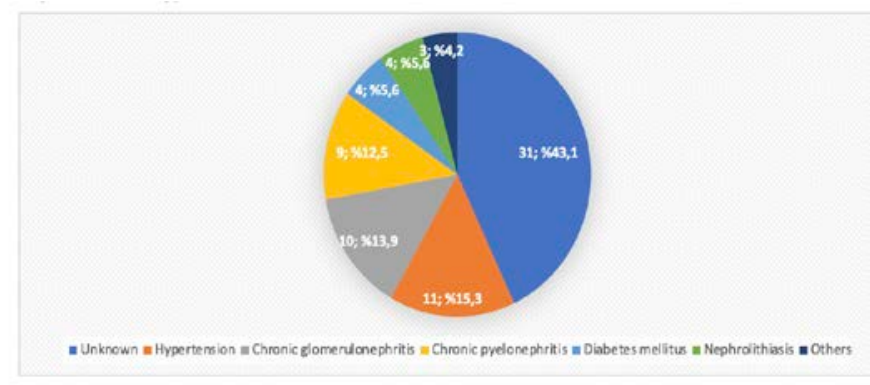

Figure 2. Etiology of Chronic Renal Failure in the Whole Patient Group

Hemodialysis was applied to 15 (48.4\%) female patients and $33(80.5 \%)$ male patients $(\mathrm{p}<0.05)$. Peritoneal dialysis was applied to 7 (22.6\%) women and $1(2.4 \%)$ men $(\mathrm{p}<0.05)$. Preemptive transplantation was performed in 7 women (22.6\%) and 7 men (17.1\%) $(p=0.55)$. The effect of gender on rejection and survival is shown in Table IV.

Table IV: The Effect of Gender on Rejection, Graft Loss and Mortality in the Whole Patient Group

\begin{tabular}{|llll|}
\hline Parameters & $\begin{array}{l}\text { Women: } \\
\text { 31 (\%) }\end{array}$ & $\begin{array}{l}\text { Men: } \mathbf{4 1} \\
\text { (\%) }\end{array}$ & $\mathbf{p}$ \\
\hline Mean patient survival (month) & $\mathbf{8 9 . 8 \pm 5 . 3}$ & $96.2 \pm 4.2$ & 0.484 \\
Mean graft survival (month) & $\mathbf{8 9 . 2 \pm 5 . 5}$ & $82.5 \pm 6.1$ & 0.357 \\
Acute rejection & $\mathbf{4 ( 1 2 . 9 )}$ & $6(14.6)$ & 1 \\
Chronic allograft nephropathy & $\mathbf{6 ( 1 9 . 4 )}$ & $13(31.7)$ & 0.239 \\
Graft loss & $\mathbf{5 ( 1 6 . 1 )}$ & $10(24.4)$ & 0.393 \\
Mortaliy & $\mathbf{5 ( 1 6 . 1 )}$ & $4(9.8)$ & 0.485 \\
\hline
\end{tabular}

When the BMI was divided into two groups as $\leq 30$ and $>30$, patient survival was found to be lower in the group with $>30(\mathrm{p}<0.05)$. In addition, when acute rejection was compared, the rate was found to be higher in patients with $>30(\mathrm{p}=0.09)$. Other comparisons in BMI are shown in Table $\mathrm{V}$.

Table V: The Effect of BMI on Rejection, Graft Loss, and Mortality in the Whole Patient Group

\begin{tabular}{|llll|}
\hline Parameters & $\begin{array}{l}\mathbf{3} 30: \\
(\%)\end{array}$ & $\mathbf{5 8} \begin{array}{l}\mathbf{3 0 :} \\
\text { (\%) }\end{array}$ & $\mathbf{1 4}$ \\
\hline Mean patient survival (month) & $\mathbf{9 7 . 1 \pm 3 . 3}$ & $80.3 \pm 10.1$ & $\mathbf{0 . 0 4 5}$ \\
Mean graft survival (month) & $\mathbf{8 2 . 9 \pm 4 . 7}$ & $91.6 \pm 8.7$ & 0.523 \\
Acute rejection & $\mathbf{6 ( 1 0 . 3 )}$ & $4(28.6)$ & 0.095 \\
Chronic allograft nephropathy & $\mathbf{1 4 ( 2 4 . 1 )}$ & $5(35.7)$ & 0.500 \\
Graft loss & $\mathbf{1 3 ( 2 2 . 4 )}$ & $2(14.3)$ & 0.719 \\
Mortality & $\mathbf{5 ( 8 . 6 )}$ & $4(28.6)$ & 0.065 \\
\hline
\end{tabular}

The mortality rate of the patients who underwent peritoneal dialysis in the pretransplantation period was $25 \%(\mathrm{p}=0.27)$ when compared with those who underwent transplantation without peritoneal dialysis. However, there was no patient in the $\leq 18$ age group who only underwent hemodialysis. All 48 patients who had only hemodialysis were in the $>18$ age group $(\mathrm{p}<0.05)$. Peritoneal dialysis was applied to 5 patients $(45.5 \%)$. Peritoneal dialysis was applied to 3 patients $(4.9 \%)$ in the $>18$ age group $(\mathrm{p}<0.05)$. The effects of the type of dialysis applied in the pre-transplant period on rejection and survival are shown in Table VI.

Table VI: The Effect of Dialysis Type on Rejection, Graft Loss and Mortality in the Whole Patient Group

\begin{tabular}{|llll|}
\hline Parameters & $\begin{array}{l}\text { Hemodialysis: } \\
\text { [p] }\end{array}$ & $\begin{array}{l}\text { Peritoneal dialysis: } \\
\text { (\%) [p] }\end{array}$ & Preemptive: 14 (\%) [p] \\
\hline Mean patient survival (month) & $\mathbf{9 5 . 6 \pm 3 . 9 [ 0 . 5 6 4 ]}$ & $74.6 \pm 12.1[0.282]$ & $87.4 \pm 8.0[0.916]$ \\
Mean graft survival (month) & $\mathbf{8 7 . 5 \pm 5 . 1 [ 0 . 6 5 0 ]}$ & $74.1 \pm 12.4[0.898]$ & $75.6 \pm 10.3[0.438]$ \\
Acute rejection & $\mathbf{6 ( 1 2 . 5 )}[\mathbf{0 . 7 1 4 ]}$ & $1(12.5)[1]$ & $3(21.4)[0.407]$ \\
Chronic allograft nephropathy & $\mathbf{1 2 ( 2 5 ) [ 0 . 5 5 2 ]}$ & $2(25)[1]$ & $5(35.7)[0.505]$ \\
Graft loss & $\mathbf{9 ( 1 8 . 8 )}[\mathbf{0 . 5 3 2 ]}$ & $2(25)[1]$ & $4(28.6)[0.480]$ \\
Mortality & $\mathbf{5 ( 1 0 . 4 ) [ 0 . 4 4 8 ]}$ & $2(25)[0.272]$ & $2(14.3)[1]$
\end{tabular}


It was observed that it was $99.9 \pm 2.5$ in patients with a dialysis duration of $\leq 12$ months and $87.5 \pm 6.4$ in patients with a duration of $>12$ months $(\mathrm{p}=0.06)$. Rejection and survival rates are shown in Table VII.

Table VII: The Effect of Dialysis Duration on Rejection, Graft Loss and Mortality in the Dialysis Patient Group

\begin{tabular}{|llll|}
\hline Parameters & $\begin{array}{l}\mathbf{1 2} \\
\text { months: }\end{array}$ & $\begin{array}{l}\text { >12 } \\
\text { months: }\end{array}$ & $\mathbf{p}$ \\
& $\mathbf{2 8}(\%)$ & $\mathbf{3 0}(\%)$ & \\
\hline Mean patient survival (month) & $\mathbf{9 9 . 9 \pm 2 . 5}$ & $87.5 \pm 6.4$ & 0.063 \\
Mean graft survival (month) & $\mathbf{9 3 \pm 5 . 2}$ & $80 \pm 7.3$ & 0.104 \\
Acute rejection & $\mathbf{3 ( 1 0 . 7 )}$ & $4(13.3)$ & 1 \\
Chronic allograft nephropathy & $\mathbf{6 ( 2 1 . 4 )}$ & $8(26.7)$ & 0.641 \\
Graft loss & $\mathbf{3 ( 1 0 . 7 )}$ & $8(26.7)$ & 0.121 \\
Mortality & $\mathbf{1 ( 3 . 6 )}$ & $6(20)$ & 0.104 \\
\hline
\end{tabular}

\section{DISCUSSION}

The most important problem in the CKD process is irreversible reduction of kidney functions and progression of the disease to the ESRD stage, regardless of the etiology causing to the kidney disease. In patients with ESRD, hemodialysis, peritoneal dialysis or kidney transplantation are preferred among renal replacement therapies. The main goal in kidney transplantation is graft and patient survival. Therefore, the choice of recipient and donor is of great importance. Especially the experiences and options in immunosuppressive therapy, a decrease in the frequency of rejection and thus an increase in patient and graft survival have begun to be observed. In the study conducted by Mateu et al. in which 3365 kidney transplant patients were evaluated, rejection was shown to have a significant $(\mathrm{p}<0.001)$ effect on graft loss, but it was not found to be statistically significant in terms of patient survival ${ }^{8}$. Again, in the study of Saygll et al., it was shown that graft survival decreased in patients who developed acute rejection $(p<0.05)^{4}$. In our study, we found that acute rejection had a negative effect on graft loss and patient survival, but this result was not statistically significant. We found that chronic allograft nephropathy had a statistically significant effect on graft loss $(p=0.002)$. It is also known that acute rejection is a risk factor for chronic allograft nephropathy ${ }^{9,10}$. In the study conducted by Schwarz et al. in which 258 patients were evaluated, chronic allograft nephropathy was more common in patients who developed acute rejection $(p=0.046)^{10}$. Consistent with the literature, in our study, the risk of developing chronic allograft nephropathy $(p=0.017)$ was found to be higher in patients who had acute rejection. All these show the importance of immunosuppressive therapy better.

In our study, when the etiologies of ESRD in kidney transplant patients were examined, hypertension comes first. Hypertension is followed by chronic glomerulonephritis and chronic pyelonephritis. With the inclusion of pediatric/adolescent patients in our study, glomerulonephritis and obstructive nephropathies are at the forefront rather than DM in the etiology. In the data of the Turkish Society of Nephrology (TND), DM takes the first place $^{11}$. In another study in our region, hypertension is in the first place in the etiology of ESRD, similar to our study ${ }^{12}$.

In our study, it was observed that hemodialysis (71.4\%) was mostly applied to patients who received transplantation from a living donor in the pre-transplant period. In the data of the TND 2019 registration system, it is seen that the most common preemptive (57.4\%) transplant is done to those who have transplanted from a living donor11. Our peritoneal dialysis frequency is similar to TND data. Considering the patients who received cadaveric transplantation, it is seen that the frequency of peritoneal dialysis (31.3\%) is higher than TND data $(8.3 \%)$ in our center 11 . In addition, among all patient groups, we found that peritoneal dialysis was applied more frequently $(p=0.011)$ in the pre-transplantation period in patients who received transplantation from a cadaveric 
donor and that these data were statistically significant.

The inflammatory and uremic burden brought on by long-term ESRD triggers systemic complications, mainly cardiovascular, and impairs renal blood flow and function. For this reason, keeping the dialysis period short and transplanting at the most appropriate time affects patient and graft survival in patients undergoing renal replacement therapy. In the study conducted by Rumyantzev et al., in which the effect of ESRD duration on kidney transplantation was investigated, it was shown that graft survival started to decrease in relation to the increase in the time passed after the diagnosis of ESRD (especially after the 6th month $)^{13}$. In our study, positive results were observed in graft and patient survival in patients who underwent dialysis for $\leq 12$ months ( $p=0.104)$. In another study by Zhang et al., dialysis times before transplantation were examined; It has been shown that the mean duration of dialysis in transplant recipients from living donors is shorter than those from cadavers $^{14}$. In our study, it was observed that the mean duration of dialysis was significantly shorter in patients who underwent dialysis in the pre-kidney transplant period compared to those who received transplantation from a cadaver $(\mathrm{p}<0.001)$. This is due to the long wait for cadaver transplantation by patients who do not have a living donor.

The effect of both donor and recipient obesity on survival in kidney transplantation has been investigated. In the meta-analysis study conducted by Lafranca et al., it was observed that it had a negative effect on graft survival and an increase in acute rejection ${ }^{15}$. In our study, we found statistically significantly lower patient survival in patients with BMI>30 ( $\mathrm{p}=0.045)$.

In conclusion, a successful kidney transplant is determined by many factors that affect shortterm and long-term graft survival. Our study showed that long-term dialysis programs and recipient-donor obesity seriously affect patient survival. In addition, prevention of rejection has a positive effect on patient and graft survival. Therefore, continuous, and regular follow-up of kidney recipients in experienced centers after transplantation is extremely important.

Ethics Committee Approval:This study was approved by Dicle University Faculty of Medicine local ethics committee (22.10.2020/48).

Conflict of Interest: The authors declared no conflicts of interest.

Financial Disclosure: The authors declared that this study has received no financial support.

\section{REFERENCES}

1. Kidney Disease: Improving Global Outcomes (KDIGO) CKD Work Group. KDIGO 2012 Clinical Practice Guideline for the Evaluation and Management of Chronic Kidney Disease. Kidney inter., Suppl. 2013; 3: 1-150.

2. Süleymanlar G, Utaş C, Arinsoy T, et al. A population-based survey of Chronic Renal Disease In Turkey--the CREDIT study. Nephrol Dial Transplant. 2011 Jun; 26: 1862-71.

3. Anderson J and Glynn LG: Definition of chronic kidney disease and measurement of kidney function in original research papers: A review of the literature. Nephrol Dial Transplant 2011; 26: 27938.

4. Saygilı ES, Seyahi N, Durak H, et al. Greft sağkalımını etkileyenfaktörlerin transplant böbrekbiyopsileriyledeğerlendirilmesi. Dicle Med J (2018) 45: 237-44.

5. Choo SY. The HLA System: Genetics, Immunology, Clinical Testing, and Clinical Implications. Yonsei Med J. 2007 Feb 28; 48: 11-23.

6. Koçak H. Postransplant Erken DönemMedikalKomplikasyonlar.

TransplantasyonNefrolojisi 2016 Ankara. 59-64.

7. Khan H, Mubarak M, Aziz T, et al. Prevalence and risk factors for early chronic allograft nephropathy 
in a live related renal transplant program. J Nephropathol. 2014; 3: 69-79.

8. Mateu LMP, Calabuig AS, Plaza LC, Esteve AF. Acute rejection and late renal transplant failure: risk factors and prognosis. Nephrol Dial Transplant. 2004 Jun;19 Suppl 3iii38-42.

9. Grinyo JM, Saval N, Campistol JM. Clinical assessment and determinants of chronic allograft nephropathy in maintenance renal transplant patients. Nephrol Dial Transplant. 2011; 26: 3750-5.

10. Schwarz A, Mengel M, Gwinner W, et al. Risk factors for chronic allograft nephropathy after renal transplantation: a protocol biopsy study. Kidney Int. 2005 Jan; 67: 341-8.

11. Süleymanlar G, Ateş K, Seyahi N et al. National Nephrology, Dialysis and Transplantation Registry Report of Turkey 2019.
12. Ay N, Kaya S, Cicek N, Bahadır MV. BöbrekTransplantasyonuVerilerimiz; Diyarbakır'da Tek Merkez Deneyimi. Dicle Med J (2017); 44: 199204.

13. Rumyantzev AG, Hurdle JF, Scandling J, et al. Duration of end-stage renal disease and kidney transplant outcome. Nephrol Dial Transplant. 2005 Jan; 20: 167-75.

14. Zhang H, Wei Y, Liu L, et al. Different Risk Factors for Graft Survival Between Living-Related and Deceased Donor Kidney Transplantation. Transplant Proc. 2018 Oct; 50: 2416-20.

15. Lafranca JA, IJermans JNM, Betjes MGH, Dor FJMF. Body mass index and outcome in renal transplant recipients: a systematic review and metaanalysis. BMC Med. 2015 May 12; 13: 111. 